\title{
Attitudes toward using the Internet for language learning: A case of Iranian English teachers and learners
}

Kia Heirati, Javad

University of Mazandaran, Babolsar, Iran (Javad.kiaheirati@yahoo.com)

Ahmadi Alashti, Leila

Semnan University, Semnan, Iran (Leila.Ahmadi1987@gmail.com)

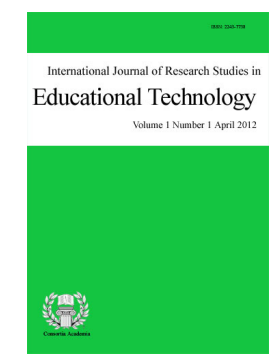

ISSN: 2243-7738 Online ISSN: 2243-7746

OPEN ACCESS

\section{Abstract}

This study was an attempt to explore and compare the attitudes of Iranian English teachers and learners toward using the Internet for language learning. Another aim of the study was to show whether there was any significant difference between males and females' attitudes toward using the Internet. To fulfill this purpose, 100 language teachers (male and female) and 100 language learners (male and female) studying English at Jihad Daneshgahi and Safir short-term Education Center in Semnan and Shokoh and ILI (international language institute) short-time educations in Ghaemshahr were selected as desired participants. Instruments used in this study were Teachers' Attitude toward Internet for Language Learning Questionnaire and Learners' Attitude toward Internet for Language Learning Questionnaire. After obtaining the raw data, SPSS software (version 20) was used to change the data into numerical interpretable information. An Independent-sample T-test was used to compare the results of the two independent groups of males and females. The findings demonstrated that most of the participants (teachers and learners) had positive attitudes towards using the Internet for language learning. Moreover, according to the results of T-test, there was no difference between learners and teachers' attitudes toward the use of the Internet for language learning. It was highlighted that both teachers and learners can benefit from the application of Internet as a tool in paving the way for the language learning process.

Keywords: teachers' attitudes; students' attitudes; internet use; internet attitude 


\section{Attitudes toward using the Internet for language learning: A case of Iranian English teachers and learners}

\section{Introduction}

In recent years, integrating computers and Internet technology in teaching and learning process changed the way in which instruction was delivered to students. The Internet plays a great role in second/foreign language teaching and learning. According to Yang and Chen, (2007), learners have access to many English language resources if they use computers and Internet in language classes. They can improve their listening, speaking, reading, and writing skills through real world situation. Because of the widespread use of computers and Internet in educational settings, language teachers are motivated to implement this technology in their classes in order to facilitate language teaching and learning process. Educators are the real representatives of utilizing technologies in language learning (Albirini, 2004).

One important factor which influences the use of educational technology in classes is the attitudes of teachers toward integrating Internet in their language classes. Teachers' attitudes toward technology use can be concerned as a facilitating or hindering factor, which give them more comfort or obstacle to utilize technology in their educational environments (Kim, 2002). Computers and Internet technology are the most effective tools among various existing technological aids in teaching and learning languages. Integrating and applying computers and Internet in a learning environment can strengthen the way that students acquire a foreign language effectively. Hence, teachers' attitudes play a fundamental role in the real utilization of technologies in classrooms.

Lots of variables and situations need to cope with each other to make a second or foreign language learner a successful one. Among these many factors is attitude, which is the main focus of this study. As we are living in the era of modern technology, therefore, the future needs and requirement of students must be addressed. The future planning is the jurisdiction of policy making institutions and departments such as planning commission, policy institute, etc. The present study enables future policy makers to provide Internet facilities to future generations.

Integrating computers and Internet technology in teaching and learning process changed the way in which instruction was delivered to students. There is not sufficient data available on the attitudes of English language teachers' and learners' regarding the use of the Internet for learning English in a foreign context such as Iran. Thus, this research focused on the attitudes of foreign language teachers and learners toward Internet-based language instruction and also takes into account the differences in attitudes that may take place between male and female subjects. As attitudes can affect learning level positively or negatively, the major purpose of the present study was to explore the attitudes of Iranian English teachers and learners toward using the Internet for language learning. Also, it was aimed to see if these two important groups differ in their attitudes toward using the Internet for the sake of language learning. Moreover, it was explored if gender factor might affect their attitudes.

\subsection{Significance of the study}

The results of the study can be significant to English language teachers, language learners, material designers and researchers, policy makers, ministry of education and whoever is interested in EFL (English as a Foreign Language). Efficacy of a new teaching approach is irreducibly tied to the attitude of the teacher. By encouraging teachers to reflect on their experiences and the challenges they face, decision makers can better ensure productive use of new technological innovations in education. If using the Internet turns out to have positive effects on the language development of EFL learners, language teachers can provide their students with 
Attitudes toward using the Internet for language learning: A case of Iranian English teachers and learners

some exercises and tasks and encourage their students to do them by using the internet. The teachers may also find it significant to make use of these tasks as the input is provided for their learners. The students can also, as a self-assigned exercise, find different exercises on the internet which are the same as given ones and do them in order to increase their knowledge of English.

\subsection{Research questions}

As to the objectives of the study in terms of exploring the attitudes of teachers and learners toward Internet application in language learning, the following research questions can be proposed:

$>\quad$ What are the attitudes of English language teachers toward using the Internet for language learning?

$>\quad$ What are the attitudes of English language learners toward using the Internet for language learning?

$>\quad$ Do English learners differ from English teachers in terms of their attitude toward using the Internet in language learning?

$>$ Does gender factor influence teachers' attitudes toward using the Internet in education and language instruction?

$>\quad$ Does gender factor influence learners' attitudes toward using the Internet for languages learning?

\section{Review of literature}

In today's world, the role of technology seems to be eye-catching in a sense that most schools and private language institutes benefit from the application of technology in order to create a better atmosphere with the purpose of making the learning process more enjoyable and at the same time more effective. In fact, the appropriate use of technology in education should be practiced by its supporters who seem to believe that it can facilitate the learning process and cause the modern education to be distant from traditional educational instruments making the class boring and teacher-centered, which appears to deprive students from more interaction in the class. As positive beliefs about technology has been raising in recent years, many countries are to make their best attempts to apply technological equipment in the classroom to enhance the sort of interaction that may be caused by these up-to-date instruments (Brown \& Warschauer, 2006).

Not only have human beings highlighted the indispensable role of technology in educational environments, but governments and policy makers also seem to be in agreement with the implementation of technological tools in a broader educational atmosphere as Scheffler and Logan (2000) highlighted the use of educational technology in the language learning process by adding this point that "in an increasingly technological and interconnected world, policymakers, educators, and the general public recognize the importance of computer knowledge and skills to the daily lives of individuals and for national economic competitiveness" (p. 305).

\subsection{Internet in language teaching and learning}

The Internet is a global network of networks through which computers communicate. It is an infrastructure consisting of computers, cables, wires, and other telecommunication devices plus the protocols to allow these computers to easily communicate with each other. The Internet has had a profound effect on almost every aspect of our lives, changing the way we do the business, communicate, and even educate ourselves.

Besides being a technological tool, the Internet can also be used as a pedagogical tool for enhancing language learning and teaching. As Wilson (1995) states, teachers are employing the Internet to access libraries throughout the world; to communicate with parents and students; to acquire instructional materials; to share lesson plans, curriculum ideas, and courseware; to connect students from different cultures to let them share their views and concerns about the world; and to download current information beneficial for classroom use. 
Kia Heirati, J., \& Ahmadi Alashti, L.

Additionally, it becomes possible for language teachers to teach the second language culture via the web-based language activities, which allow the learners to be exposed to the target culture as well as the target language (Beltz, 2003). Internet facilitates comprehension in listening and reading via audio and visual input and provides a vast range of authentic resources as well.

The Internet offers the best way to learn language rather than immersion in an English speaking milieu. The advantages of online learning can be summarized under the following headings:

$>$ Access: Internet offers the possibility to experience English without the need of traveling. Even without the need of leaving home or bedroom.

$>$ Flexibility: Internet allows users to learn language when they want, where they want.

$>$ Response: Internet offers the possibility of instant feedback to learners. This greatly enhances the learning experience.

$>$ Repeatability: learners can encounter the language in a repetitive fashion until mastery is achieved.

Modality: Internet is a multi-modal learning tool. It stimulates in a rich sensory and cognitive and thus fertilizes language acquisition successfully.

$>$ Specificity: Internet allows the language learner choice and variety in both what and with who will be learned. Learning can be tailored to the language learner's precise makeup and needs.

The Internet-mediated communication allows users to share not only brief messages, but also create lengthy documents, thus facilitating collaborative writing (learning). Furthermore, learners can share graphics, sounds and video. Therefore, Internet helps create an environment where authentic and creative communication is integrated into all aspects of the course.

\subsection{Attitudes toward Internet}

It should be kept in mind that learners' perceptions towards technologies and their presence in their English classes as teaching tools may have a great effect on the success or failure of the teaching and learning processes. From Lasagabaster and Sierra's (2003) point of view, learners are considered as potential contributors to the development of the language learning tools. Hence, researchers should take learners' opinions into consideration in evaluating these technologies. The identification of learners' perceptions towards the use of Internet may help teachers cope with the possible problems in the actual integration of it in the learning process.

A significant number of studies address students' attitudes towards the application of computer technology in classrooms (e.g. Lam, 2000; Arkin, 2003). In a study, Stepp-Greany (2002) reported students' perceptions of the learners about technology at a beginning Spanish class. She stated that benefits for the students "include increased motivation, improvement of self-concept and mastery of basic skills, more student-centered learning, and engagement in the learning process, and more active processing, resulting in higher-order thinking skills and better recall” (p. 165).

In another study conducted by Aytekin (2004) in Eastern Mediterranean University, 173 undergraduate and M.S. level students' perceptions and attitudes were analyzed through the prepared questionnaire about Internet. Students' responses to the questionnaire were quantitatively analyzed according to gender, education level of their mothers and fathers, having computer at their homes, having Internet education and student's positions. Results indicated that students strongly agreed on having Internet and using computer in their homes; all values were higher than the standard value.

One important factor which influences the use of educational technology in classes is the attitudes of teachers toward integrating Internet in their language classes. Having positive attitudes toward Internet use helps 
teachers to increase learning to utilize this technology in the teaching and learning process. It means that positive attitudes of teachers should be developed. In fact, holding positive attitudes can stimulate teachers to learn the required skills which are essential for applying technology-based exercises and activities in classes. In a study by Mcalister, Dunn, and Quinn (2005), teachers showed positive attitudes toward using technology although they did not have enough experience about technology utilization. The researchers concluded that more time, training, and value should be given to teachers who are as a model for students. The accessibility to suitable software and teachers' tendency to utilize that software have a positive influence on teachers' attitudes toward the acceptance of technology in their classes (Sepehr \& Harris, 1995).

On the other hand, teachers' negative attitudes towards technology could affect negatively on students' perceptions of computer technology (Weil, Rosen, \& Wugalter, 1990). If teachers show negative attitudes to the change of traditional instructional practices, the new curriculum may not be successful. For the use of technology in the educational environment, the change encompasses both the learning of new proposed technology skills and pedagogies (see Woodrow, 1987; Saye, 1998).

To sum up, it seems that the application of Internet as an educational tool to facilitate the process of language learning has been attended by scholars in the related field. However, studies done in terms of teachers' and learners' attitudes show that there seems to be a gap in that how these attitudes should go in line together to reach better agreement regarding positive attitudes of using Internet in the classroom held by both teachers and learners. If a precise comparison of teachers' and students' attitudes toward Internet is gained, a better educational setting can be designed with respect to the use of Internet in the classroom to assist both learners and teacher to enjoy learning and teaching.

\section{Methodology}

\subsection{Participants}

The participants of this study were EFL (English as a foreign language) intermediate, upper-intermediate, and advanced (according to the records of the institutes) students who were studying at Shokoh Institute and ILI (Iran Language Institute) short-time educations in Ghaemshahr and Safir and Jihad Institutes in Semnan, Iran. As to the sampling of participants, the study benefitted from convenient sampling due to making the best use of time and collecting the desirable data. Dornyei (2007) argues that researchers apply this type of sampling to save time and prepare willing participants based on the purpose of the research. They were both males and females with the average age range of 16 to 30 years old. The original sample (for learners) comprised 100 participants and fortunately all of them returned the questionnaires. Since gender was one of the variables in this study, subjects were both males and females. So, 50 of participants included male students and 50 of them were females.

The participants also included 100 English teachers with teaching experience from one year to more than twenty years and the age range of 22 to 50 years old. All these teachers had teaching experience at above-mentioned institutes.

\subsection{Instruments}

The present study employed quantitative research method using questionnaires. Considering the purpose and scope of the study, questionnaires made by the researchers were utilized as the primary approach to collect data from a large group of participants in a fairly short amount of time. The instruments used to accomplish the research purposes were based on four questionnaires. One of them was 'Pre-service Teachers' Attitudes towards the Use of and Needs for Internet Applications in English Language Teaching Questionnaire', which was adapted from the master thesis of Yutdhana (2004), and the validity and reliability checks were done by Külekçi (2009), which is calculated by the Cronbach's alpha reliability coefficient as 0.92. This Questionnaire consisted of two sub-scales as 'Internet Attitude Scale' and 'Self-Perception of Computing Skills Scale'. Internet Attitude 
Kia Heirati, J., \& Ahmadi Alashti, L.

Scale included 7 items. This scale was selected in order to evaluate English pre-service teachers' opinions towards using Internet applications for teaching English. Self-Perception of Computing Skills Scale included 10 items. In this scale, which consisted of two factors, the basic computer skills of the students and their educational needs related to the use of computers were evaluated.

The second one was 'Student Teachers' Perceptions toward Internet-Assisted Language Teaching and Learning Questionnaire' constructed by Shin and Son (2007). It is a questionnaire using a Likert-scale ranging from 4 (Strongly Disagree) to 1 (Strongly Agree). The questionnaire consisted of two sections: 1. a demographic section to get participants' background information; 2. a multiple-choice section with fifteen questions which concerning the student teachers' perceptions when using the Internet to enhance their EFL teaching and learning. The third questionnaire was 'Attitudes toward ICT (Information and Communication Technologies)' developed by Albirini (2004); a 5-point Likert-type scale with 20 items, ranging from "strongly disagree" (1 point) to "strongly agree" ( 5 points) with reliability of 0.90 ; while, the last one was 'Computer Attributes Scale', developed by Albirini (2004), with the purpose offending out how English language teachers consider computers in 55 educational contexts, more specifically in classroom settings and language instruction. Computer Attributes Scale consisted of eighteen Likert-type items with the reliability of 0.86 .

Based on these four standard questionnaires, two questionnaires were constructed based on the scope of the present study to answer the research questions underlying the study. Although the questions did not change substantially in order to preserve the reliability and validity of questionnaires, they were piloted, and on the basis of the received feedback, the questions were modified to make it easier for the participants to understand and answer each of the final questionnaires that included 40 items. Hence, the final two questionnaires (see Appendix $1 \& 2$ ) consisted of 40 Likert-type items on a five-point scale, ranging from 'strongly disagree' (1 point) to 'strongly agree' (5 points) to explore teachers' and learners' attitudes toward using the Internet for language learning.

\subsection{Validation and reliability of instruments}

In order to assure the validity and reliability of the modified questionnaires, a pilot study was carried out and then the reliability of them was estimated with Cronbach's Alpha, which shows that both instruments contain high reliability value. The reliability of these questionnaires is as the following:

Table 1

Reliability of Teachers' Attitude toward Internet for Language Learning Questionnaire

\begin{tabular}{cc}
\hline Cronbach's Alpha & No. of items \\
\hline 0.809 & 40 \\
\hline
\end{tabular}

Table 2

Reliability of Learners' Attitude toward Internet for Language Learning Questionnaire

\begin{tabular}{cc}
\hline Cronbach's Alpha & No. of items \\
\hline 0.809 & 40 \\
\hline
\end{tabular}

\subsection{Procedures}

A pilot study preceded the actual administration of the questionnaires. Forty volunteers participated (25 learners and 15 teachers) in the piloting phase. The instructions of how to fill in the questionnaires were explained orally by one of the researchers. The piloting brought about many benefits regarding the way the questionnaires were administered and the items included in the final questionnaires. For instance, it gave the researchers a clue to the approximate time needed for completing the questionnaires and what needed to be clarified by the researchers before participants started completing the questionnaires. It also helped with the 
Attitudes toward using the Internet for language learning: A case of Iranian English teachers and learners

wording of some items. For example, the term 'remediation' and 'attentive' were unfamiliar to younger learners so that synonyms were added in parenthesis as they mean 'solution' and 'careful'.

Prior to the administration of the questionnaires, a face-to-face meeting was held with the executive director of the studied institutes. Permission for data collection for the study was requested. After the approval, 200 questionnaires were distributed among EFL learners and teachers in Ghaemshahr and Semnan, Iran. The application of the research instrument- the questionnaires - was performed directly by the researchers. One of the researchers attended the class in person and explained the goal of the research in Persian (learners' native language) to prevent any ambiguities. She also added that participation in the study is free and there is no need to write their names. So, participants were assured of the anonymity and privacy of the recorded data. They were told that there was no right or wrong answer.

As far as all the participants were interested in the topic of the study and the final result of the research, they were eager to cooperate and answer all the parts meticulously. So, 200 questionnaires were returned with a $100 \%$ return rate. On average, the participants responded to the questionnaires in 15 minutes.

\subsection{Data analysis}

As Brown (2001) rightly points out, having collected our data is half the battle, and now we must address the other half, the processing of the stacks of completed questionnaires and multiple pages of notes of quantitative scores. Hence, after collecting and arranging the data, the next step is to analyze it using a set of mathematical procedures, called 'statistics'. These range from simple descriptive statistics assessing frequency, mean, and standard deviation, and depicting histogram for general distribution of the variables across the sample.

The researchers used an Independent-sample T-test to compare the results of attitudes of teachers and learners of the two groups of males and females that were independent of each other. The reliability of the questionnaires was also estimated. The collected data were coded and analyzed with SPSS (Statistical Package for the Social Sciences) version 20. The inferential statistics helped the researcher to decide whether the results that were observed in the sample were powerful enough to generalize to the whole population because descriptive statistics do not allow drawing any general conclusions that would go beyond the sample.

\section{Results}

The goals of the study were to find:

$>\quad$ The attitude of English language teachers toward using the Internet for language learning.

$>\quad$ The attitudes of English language learners toward using the Internet for language learning.

$>\quad$ Whether there are differences between English learners and English teachers in terms of their attitude toward using the Internet in language learning.

$>\quad$ The effect of gender on both teachers and learners' attitudes about using the Internet in language learning (fourth and fifth research questions)

To answer the research questions, both descriptive and inferential statistics were used. All the reported results were analyzed through SPSS 20 and Excel 2010, which were obtained by using T-test and Pearson-Product Moment Correlation. Before doing inferential tests and deriving results about the hypotheses of the study, the researchers did some descriptive statistics on the variables of this study and offered a tidy way of presenting the data they collected. The result of descriptive statistics for the demographic variables was the following. Table 3 displays information about the total numbers of teachers who participated in this study. 
Kia Heirati, J., \& Ahmadi Alashti, L.

As it is illustrated in Table 3, the sample included equal number of both gender (50 percent), it means half of the participants were males and the other half were females. Table 4 displays information about the total numbers of learners who participated in this study.

Table 3

Descriptive Statistics of Gender for Teachers

\begin{tabular}{clcccc}
\hline & & Frequency & Percent & Valid percent & Cumulative percent \\
\hline \multirow{3}{*}{ Valid } & Male & 50 & 50.0 & 50.0 & 50.0 \\
& Female & 50 & 50.0 & 50.0 & 100.0 \\
& Total & 100 & 100 & 50.0 & \\
\hline
\end{tabular}

Table 4

Descriptive Statistics of Gender for Learners

\begin{tabular}{clcccc}
\hline & & Frequency & Percent & Valid percent & Cumulative percent \\
\hline \multirow{3}{*}{ Valid } & Male & 50 & 50.0 & 50.0 & 50.0 \\
& Female & 50 & 50.0 & 50.0 & 100.0 \\
& Total & 100 & 100 & 50.0 & \\
\hline
\end{tabular}

According to Table 4, it included equal number of samples (50 percent), it means half of the learners were males and the other half were females. Internet attitude levels of participants, the means, number and standard deviation for learners and teachers who participated in this study are presented in Table 5.

Table 5

Students and Teachers' Means and Standard Deviation in the Scale of Internet Attitude

\begin{tabular}{lcccccc}
\hline & $\mathrm{N}$ & Maximum & Minimum & Mean & Std. Deviation & Std. Error Mean \\
\hline Learners & 100 & 188 & 32 & 150.86 & 9.66476 & .96648 \\
Teachers & 100 & 185 & 36 & 153.58 & 10.20981 & 1.86405 \\
\hline
\end{tabular}

Table 5 represents the number, mean and standard deviation regarding the students and teachers' attitude toward using the Internet for language learning, and it has shown that with the high mean, 150.86 for learners and 153.58 for teachers, participants in this study had positive attitudes toward using the Internet for language learning. For investigating the difference between English learners and teachers in terms of their attitude toward using the Internet in language learning, T-test was applied. The result of this test is as the following:

\section{Table 6}

T-Test Analysis on Learners' and Teachers' Attitude toward Using the Internet for Language Learning

\begin{tabular}{llc}
\hline & Df & T \\
\hline Teacher and learners & 98 & 4.271 \\
\hline
\end{tabular}

Note. *at the 0.05 alpha level

As Table 6 shows, the value of $\mathrm{T}$ for the teachers and learners is equal to 4.271, which makes it to validate, with 98 degrees of freedom at a significance level of 0.05 . According to the results of the study, there was no significant difference between the attitudes of two groups toward using the Internet for language teaching and learning, highlighting this fact that both teachers and learners' attitudes about Internet were in line together. The fourth research question was to find out the relationship between teachers' attitudes about Internet and gender. To answer this question, the researchers used the T-test for the two independent samples. The result of the T-test is presented in Tables 7 and 8. 


\section{Table 7}

Teachers' Attitudes toward Using the Internet Regarding Their Gender

\begin{tabular}{llcc}
\hline Gender & $\mathrm{N}$ & Std. Deviation & Mean \\
\hline Male & 50 & 13.61 & 151.65 \\
Female & 50 & 11.27 & 154.86 \\
\hline
\end{tabular}

Table 8

An Independent Sample T-Test on the Males and Females' Attitude of Teachers

\begin{tabular}{lccccccc}
\hline & \multirow{2}{*}{$\mathrm{N}$} & \multicolumn{3}{c}{ Paired Differences } & \multirow{2}{*}{ T } & Df & Sig (2-tailed) \\
\cline { 3 - 5 } & & Mean & Std. Deviation & Std. Error Mean & & & \\
\hline Teacher & 100 & 153.58 & 10.20981 & 1.86405 & 52.377 & 99 & 2.16 \\
\hline
\end{tabular}

As it is illustrated in Tables 7 and 8 above, the two means are very close to each other. And as Table 8 shows, there is no difference between teachers' attitudes toward using the Internet for language learning in relation to their gender $(\mathrm{Sig}=2.16)$. To answer the fifth research question i.e. 'does gender factor influence learners' attitudes toward using the Internet for languages learning?' T-test was also applied to find the relationship between the independent variables. The result of the T-test is presented in the following tables.

Table 9

Learners' Attitudes toward Using the Internet Regarding Their Gender

\begin{tabular}{|c|c|c|c|}
\hline Gender & $\mathrm{N}$ & Std. Deviation & Mean \\
\hline Female & 50 & 13.34 & 153.42 \\
\hline Male & 50 & 12.27 & 150.87 \\
\hline
\end{tabular}

Table 10

An Independent Sample T-Test on the Males and Females' Attitude of Learners

\begin{tabular}{lccccccc}
\hline & \multirow{2}{*}{$\mathrm{N}$} & \multicolumn{3}{c}{ Paired Differences } & \multirow{2}{*}{$\mathrm{T}$} & Df & \multirow{2}{*}{ Sig (2-tailed) } \\
\cline { 3 - 6 } & & Mean & Std. Deviation & Std. Error Mean & & & \\
\hline Learner & 100 & 150.86 & 9.7205 & .97205 & 98.163 & 99 & .399 \\
\hline
\end{tabular}

As it is shows in Tables 9 and 10, the two means are very similar and, as table 10 shows, there is no difference between learners' attitudes toward using the Internet for language learning regarding their gender $(\operatorname{Sig}=0.399)$.

\section{Discussion and conclusion}

As to the results, there was no statistically significant difference between total attitude scores and gender regarding use of Internet in instruction and also both teachers and learners had positive attitude toward using of the Internet for language learning. Data from this study showed that approximately most of EFL teachers felt that Internet can create a rich learning environment to them and nearly all of them confirmed that it is a useful tool for helping them to achieve the future teaching purpose; and most of EFL teachers believed that websites are useful for their future teaching. The data revealed that most EFL teachers recognized the functions of Internet-assisted language instruction and regarded Internet as an important educational tool in their future teaching. In a word, most EFL teachers of this study had strong beliefs that integrating modern technology into language instruction has become an unavoidable tendency in the ESL (English as a second language) and EFL education. 
Kia Heirati, J., \& Ahmadi Alashti, L.

Also the result of this study shows that the attitudes of English students towards the use of the Internet are positive and high, which are the same as the English teachers. Most EFL students of this study confirm that the Internet can provide them a rich learning environment through their previous learning experiences. These EFL students are also positive for using the Internet to improve their English skills. Indeed, inspired high development of modern technology, the computer and the Internet have already become a part of our daily life in this digital era.

The results of this study are in line with Sadaf, Newby, and Ertmer (2012) who investigated pre-service teachers' behavioral, normative, and control beliefs concerning their intentions to use Web 2.0 technologies in their classrooms. The results recommended that pre-service teachers' intentions to use Web 2.0 technologies were associated to their beliefs about the value of these technologies for improving learners' learning and engagement, its ease of use, its ability to meet the learners' needs, the participants' high self-efficacy in use, and its potential for affording learners anytime/anywhere access to learning and interaction. Sanchez, Marcos, Gonzales, and GuanLin (2012) found that teachers have a highly positive attitude toward ICT (Information and Communication Technologies), but its use in class is scarce due to teachers' innovative processes. In another study conducted by Hismanoğlu and Hismanoğlu (2010), the findings of the research revealed that most of the teachers had positive attitudes toward using the Internet and they were aware of the potential of the Internet implementation in language education by going far beyond the traditional concepts and methodologies.

The results of this research are not in alignment with that of Tekerek and Ercan (2012) who investigated how the Internet attitude varies according to sex. In their findings, male teachers displayed more positive attitude than female teachers for using the Internet in education and teaching. But, this study found no significant difference between males' and females' attitudes toward using the Internet for language learning. Taking all of these findings into accounts, Iranian EFL teachers and learners are somehow highly familiar with the new technologies and have highly positive attitudes towards the integrating them into classrooms to improve their learners' different skills. They are also willing to use these technologies. Thus, the only problem not to use and integrate them in the class is that the institutes are not equipped so well with the appropriate platforms and technologies. While the teachers are prepared to use and have the necessary information and knowledge, there is not the primary equipment to apply them in the classrooms. So, the policy makers and the managers of institutes should pay more attentions on the existing problem and try to find a practical solution for these them.

\subsection{Implication}

Language learning in the $21^{\text {st }}$ Century presents both unparalleled opportunities and extraordinary challenges, many of which are the direct result of computer technology (Ostendorf, Shriberg, \& Stolcke, 2005). Indeed, the traditional EFL pedagogy and modern computer technology are to combine to form a new EFL instructional approach. The computer assisted language programs and the Internet resources have now become the indispensable supplementary of EFL education. Educators recognized that utilizing computer technology can be convenient to create both independent and collaborative learning environments and provide students with language experiences as they move through the various stages of second language acquisition (Rost, 2002; Taylor \& Gitsaki, 2003). Through the use of the Internet, word processors, presentation software, multimedia, hypermedia, drill and practice programs, the EFL students can engage in individualized instruction designed to meet their specific needs and participate in cooperative projects that foster communication with peers in their classrooms and throughout the global community.

However, although most of EFL teachers in this study had positive experiences and attitudes toward the use of Internet assisted language instruction and considered technology to be an important approach in their future teaching careers, many of them were still unsure whether they possess the skills and knowledge of technology to integrate technology into their future EFL classrooms. To overcome the problem and help EFL teachers to be technology proficient teachers in the future, EFL schools and instructors should provide more learning opportunities, create appropriate EFL approach with technology curricula, construct rich technology 
Attitudes toward using the Internet for language learning: A case of Iranian English teachers and learners

environments, and offer professional technology training to EFL teachers. In addition, technology cannot replace traditional teaching approaches, but today's educational system cannot grow and will not succeed without access to computers and the Internet. Therefore, EFL instructors should also train EFL teachers for equipping with relevant abilities and competencies especially in on-line literacy and communication skills and assist them to build correct technology attitude and belief in order for teachers to employ computer technology and the Internet to strengthen their EFL teaching in the future.

Also based on the findings of this study, the use of the Internet as a tool to meet the needs of L2 learners has a great potential in the development of the second language skills. The latest advancing computer technology has been providing L2 learners with innovative opportunities to develop one of the four language skills beyond the classroom's walls. This new technology provides students with autonomy to learn on their own time and anywhere. Overall, Internet provides students with original L2 audio, video, readings and the possibility of face-to-face interaction with L2 native speakers. Researchers agree that Internet provides unique experiences to the L2 learners since new technology has added new features like on-line dictionaries and e-readers to facilitate L2 learning. Internet technology would not reach all its full potential if L2 teachers were not receiving proper training on the implementation of Internet technology and have positive attitudes towards it. L2 teachers must be ready to adapt Internet to the curriculum and the students' needs. Teachers will benefit from the study findings by gaining a better understanding of the importance of the Internet and the advantages of technology use as a tool to learn a second or foreign language.

The study reveals that computer and Internet is playing pivotal role in language learning and teaching. It is easier to search through Internet as compare to sit in the library and collect information. Therefore, it suggests publishers and writers to shift from their attention from hard binding books to soft copies of their finding and make available on the Internet so that more learners and teachers can get access to this invaluable information. A vast majority of the students are using Internet in their educational life. They can use Internet and find interesting things according to their own choice for reading and learning new language. That would help saving time and resources both that is going to be scarce in $21^{\text {st }}$ millennium. The Internet use will encourage our younger generations to make use of modern technologies to accomplish their ambition for learning a second or foreign language. As a final point, positive attitudes can contribute to create a real-life language learning environment via the Internet without forgetting that the Internet is not a purpose but only a tool for all learning necessities.

\subsection{Suggestion for further research}

Based on the result of this study, the following suggestions for further research can be offered:

Future research should be conducted to broaden the scope of the present study. As it was mentioned before, the present study was conducted with 100 upper intermediate and advanced students and also 100 teachers were participated. A similar research can be done with EFL learners at different levels for example beginners, pre -intermediates and also EFL teachers with different years of experiences and with greater number of subjects to further examine the generalizability of these results. Further research studies might be carried out to investigate the level of EFL teachers' ICT knowledge and their viewpoints upon the problems and limitations of using Internet tools in classrooms. Or investigate the extent to which these Internet tools are available in classrooms. The merits and demerits of using these Internet tools from both teachers' and learners' viewpoints should be examined.

Moreover, since there is no curriculum for teaching with Internet, a needs analysis may be conducted involving all the stakeholders of the institution to create an effective curriculum. After determining the needs for an effective curriculum, workshops or training sessions may be given to the students and teachers. As a further study the impact of training on students and teachers may be analyzed as an experimental study. Finally, follow-up studies can include demographic variables such as learners' and teachers' age, year of learning/teaching English, university degree and make further comparisons among the possible relations of each 
Kia Heirati, J., \& Ahmadi Alashti, L.

with attitudes towards the Internet.

\section{References}

Albirini, A. (2004). Teachers' attitudes toward information and communication technologies: The case of Syrian EFL teachers. Computers and Education, 47, 373-398. http://dx.doi.org/10.1016/j.compedu.2004.10.013

Arkin, E. I. (2003). Teachers' attitudes towards computer technology use in vocabulary instruction. Unpublished masteral thesis, Bilkent University, Ankara.

Aytekin, I. (2004). Attitudes of students towards the Internet. Turkish Online Journal of Distance Education, 5(4), 25-37.

Beltz, J. A. (2003). Linguistic perspectives on the development of intercultural competence in telecollaboration. Language Learning \& Technology, 7(2), 68-117.

Brown, D., \& Warschauer, M. (2006). From the university to the elementary classroom: Students' experiences in learning to integrate technology in instruction. Journal of Technology and Teacher Education, 14(3), 599-621.

Dornyei, Z. (2007). Research methods in applied linguistics. Oxford: Oxford university press.

Hismanoğlu, M., \& Hismanoğlu, S. (2010). English language teachers' perceptions of educational supervision in relation to their professional development: A case study of northern Cyprus. Novitas-Research on Youth and Language, 4(1), 16-34.

Kim, H. (2002). Teachers as a barrier to technology-integrated language teaching. English Teaching, 57(2), $35-64$.

Külekçi, G. (2009). Assessing the attitudes of pre-service English teachers towards the use of the internet. Ahi Evran Üniversitesi Ĕ̆itim Fakültesi Dergisi, 10(3), 153-160.

Lam, Y. (2000). Technophobilia vs. technophobia: A preliminary look at why second language teachers do or do not use technology in their classrooms. Canadian Modern Language Review, 56, 389-420. http://dx.doi.org/10.3138/cmlr.56.3.389

Lasagabaster, D., \& J. Sierra. (2003). Students' evaluation of CALL software programs. Educational Media International, 40(3), 293-304. http://dx.doi.org/10.1080/0952398032000113211

Mcalister, M., Dunn, J., \& Quinn, L. (2005). Student teachers' attitudes to and use of computers to teach mathematics in the primary classroom. Technology, Pedagogy and Education, 14(1), 77-106. http://dx.doi.org/10.1080/14759390500200194

Ostendorf, M., Shriberg, E., \& Stolcke A. (2005). Human language technology: Opportunities and Challenges. Retrieved from http://www.speech.sri.com/papers/icassp2005-specialsession.pdf

Rost, M. (2002). New technologies in language education: Opportunities for professional growth. Retrieved from http://www.longman.com/ae/multimedia/pdf/MikeRost_PDF.pdf

Sadaf, A., Newby, T. J., \& Ertmer, P. A. (2012). Exploring pre-service teachers' beliefs about using Web 2.0 technologies. Computers \& Education, 59, 937-945. http://dx.doi.org/10.1016/j.compedu.2012.04.001

Sanchez, A., Marcos, J., Gonzales, M., \& GuanLin, H. (2012). In service teachers' attitudes towards the use of ICT in the classroom. Procedia - Social and Behavioral Sciences, 46, 1358-1364. http://dx.doi.org/10.1016/j.sbspro.2012.05.302

Saye, J. W. (1998). Technology in the classroom: The role of disposition in teacher gate keeping. Journal of Curriculum and Supervision, 13(3), 210-234.

Scheffler, F. L., \& Logan, J. P. (2000). Computer technology in schools: What teachers should know and be able to do. Journal of Research on Computing in Education, 31(3), 305-326.

Sepehr, H., \& Harris, D. (1995). Teachers' use of software for pupils with specific learning difficulties. Journal of Computer Assisted Learning, 11, 64-71. http://dx.doi.org/10.1111/j.1365-2729.1995.tb00118.x

Shin, H. J., \& Son, J. B. (2007). EFL teachers' perceptions and perspectives on internet assisted language 
Attitudes toward using the Internet for language learning: A case of Iranian English teachers and learners teaching. CALL-EJ Online, 8(2), 1-13.

Stepp-Greany, J. (2002). Student perceptions on language learning in a technological environment: Implications for the new millennium. Language Learning and Technology, 6(1), 165-180.

Taylor, R., \& Gitsaki, C. (2003, November). Current trends in web-enhanced language learning. Paper presented during the 29th Annual JALT International Conference, Shizuoka, Japan.

Tekerek, M., \& Ercan, O. (2012). Analysis of teachers' attitude towards internet use: Example of chemistry teachers. Creative Education, 3(3), 296-303. http://dx.doi.org/10.4236/ce.2012.33047

Weil, M. M., Rosen, L. D., \& Wugalter, S. (1990). The etiology of computer phobia. Computers in Human Behavior, 6, 361-379. http://dx.doi.org/10.1016/0747-5632(90)90014-8

Wilson, T. F. (1995). The Internet at Eagan high school. T.H.E. Journal, 22(9), 75-79.

Woodrow, J. E. (1987). Educators' attitudes and predispositions towards computers. Journal of Computers in Mathematics and Science Teaching, 6(3), 27-37.

Yang, Sh., \& Chen, Y. (2007). Technology-enhanced language learning: A case study. Computers in Human Behavior, 23, 860-879. http://dx.doi.org/10.1016/j.chb.2006.02.015

Yutdhana, S. (2004). A needs analysis of Thai high school teachers in using internet applications for teaching English as a foreign language. Unpublished masteral thesis, Washington State University, Washington.

Appendix 1. Teachers’ Attitude toward Internet for Language Learning Questionnaire

Dear teacher:

Instructions: The statements below describe attitudes toward using the Internet for language learning. Read each one and decide how much it applies to you. Circle the number that best describes how you usually think, based on the first response that comes to mind. There is no right or wrong answers.

Gender: $\quad$ Male Female

\begin{tabular}{|c|c|c|c|c|c|}
\hline Statements & $\begin{array}{c}\text { Strongly } \\
\text { Disagree } \\
(1)\end{array}$ & $\begin{array}{l}\text { Disagree } \\
\text { (2) }\end{array}$ & $\begin{array}{c}\text { Neutral } \\
\text { (3) }\end{array}$ & $\begin{array}{l}\text { Agree } \\
(4)\end{array}$ & $\begin{array}{c}\text { Strongly } \\
\text { Agree } \\
(5)\end{array}$ \\
\hline \multicolumn{6}{|l|}{ 1. Internet applications can play an important role in the classroom } \\
\hline \multicolumn{6}{|l|}{$\begin{array}{l}\text { 2. Internet applications can be used in the class to enhance the teaching of important } \\
\text { skills }\end{array}$} \\
\hline \multicolumn{6}{|l|}{ 3. Internet applications are best used for drill, remediation or reinforcement of facts } \\
\hline \multicolumn{6}{|l|}{$\begin{array}{l}\text { 4. Internet applications are best used in the classroom to promote students' } \\
\text { analytical, creative and other high order thinking skills }\end{array}$} \\
\hline \multicolumn{6}{|l|}{$\begin{array}{l}\text { 5. Internet applications can be used in the classroom to provide alternative learning } \\
\text { approaches for students who are having difficulty in learning }\end{array}$} \\
\hline \multicolumn{6}{|l|}{ 6. Using internet applications is an appropriate activity for some students } \\
\hline \multicolumn{6}{|l|}{$\begin{array}{l}\text { 7. Using internet applications can be used in the classroom to make learning more } \\
\text { interesting for all students }\end{array}$} \\
\hline \multicolumn{6}{|l|}{ 8. Information obtained from ESL/EFL websites is useful } \\
\hline \multicolumn{6}{|l|}{ 9. Creating activities based on the Internet is useful } \\
\hline \multicolumn{6}{|l|}{$\begin{array}{l}\text { 10. Through my teaching experiences, I was motivated to teach English by the use of } \\
\text { the Internet. }\end{array}$} \\
\hline $\begin{array}{l}\text { 11. Through my teaching experiences, I improved my methods through the use of } \\
\text { the Internet. }\end{array}$ & & & & & \\
\hline
\end{tabular}


Kia Heirati, J., \& Ahmadi Alashti, L.

12.Through my teaching experiences, Internet resources provided me more opportunities for good teaching

13. Through my teaching experiences, I improved my communication skills and teaching methods by e-mailing or chatting with native speakers of English on-line.

14. Through my teaching experiences, I was more attentive in Internet-assisted English language teaching classes.

15. In my belief, the Internet can provide non-native speakers of English with a rich learning environment.

16. The Internet is a useful tool for helping me achieve my future teaching purpose.

17. In my belief, Internet resources can replace textbooks.

18. In my belief, it is easy to find teaching ESL/EFL materials on the Web.

19. In my belief, ESL/ EFL Websites are useful for teaching English.

20. I think I would like to use Internet assisted language learning materials and activities in my future EFL teaching as much as possible.

21. I think I am competent to use Internet- based materials in my future teaching.

22. I think I need more technology training to improve my Internet literacy skills.

23. I think I have to further learn how to integrate Internet resources into my future teaching.

24. I can get more current information from the Internet rather than from printed materials for better teaching.

25. The Internet has become an indispensable tool in my teaching.

26. Using the Internet could speed up my teaching.

27. It is easy to locate useful information on the Internet

28. Time spent on the Internet is worthwhile for teaching.

29. The Internet is always my first choice for research for finding new methods.

30. I feel confident locating the information I need on the Internet for my teaching.

31. Internet improve education.

32. Teaching with Internet offers real advantages over traditional methods and instructions.

33. Internet cannot improve the quality of students' learning.

34. Using Internet makes the subject matter more interesting.

35. Internet is not useful for language teaching.

36. Internet has no place in the classrooms.

37. Internet allows me to create materials that enhance my teaching.

38. Internet can be an effective teaching way for teachers.

39. Using Internet for teaching is a priority for me.

40. I find using the Internet as an integral part of the educational process.

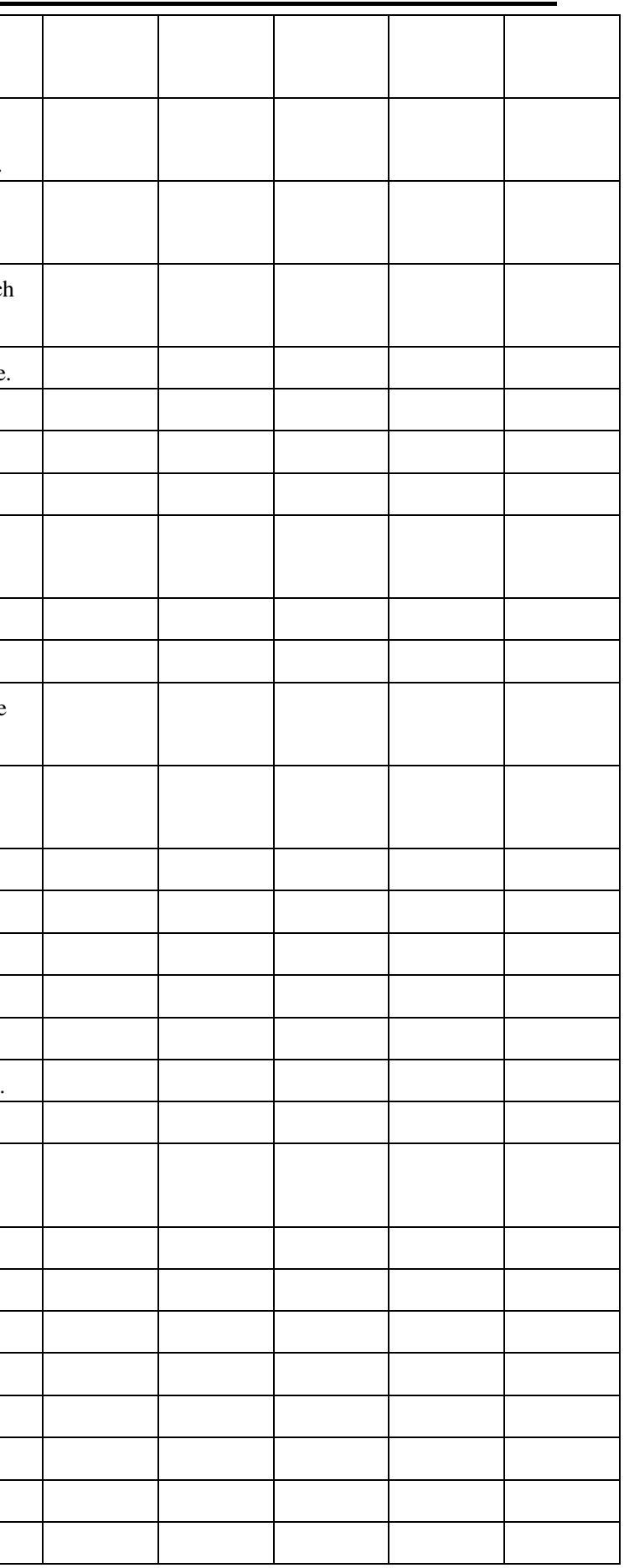


Attitudes toward using the Internet for language learning: A case of Iranian English teachers and learners

Appendix 2. Learners' Attitude toward Internet for Language Learning Questionnaire

Dear learner:

Instructions: The statements below describe attitudes toward using the Internet for language learning. Read each one and decide how much it applies to you. Circle the number that best describes how you usually think, based on the first response that comes to mind. There is no right or wrong answers.
Gender:
Male
Female

\begin{tabular}{|c|c|c|c|c|c|}
\hline Statements & $\begin{array}{c}\text { Strongly } \\
\text { Disagree } \\
(1)\end{array}$ & $\begin{array}{l}\text { Disagree } \\
\text { (2) }\end{array}$ & $\begin{array}{c}\text { Neutral } \\
\text { (3) }\end{array}$ & $\begin{array}{l}\text { Agree } \\
(4)\end{array}$ & $\begin{array}{c}\text { Strongly } \\
\text { Agree } \\
(5) \\
\end{array}$ \\
\hline \multicolumn{6}{|l|}{ 1. Internet applications can play an important role in the classroom. } \\
\hline \multicolumn{6}{|l|}{$\begin{array}{l}\text { 2. Internet applications can be used in the class to enhance the teaching of important } \\
\text { skills. }\end{array}$} \\
\hline \multicolumn{6}{|l|}{$\begin{array}{l}\text { 3. Internet applications are best used for drill, remediation (solution) or } \\
\text { reinforcement of facts. }\end{array}$} \\
\hline \multicolumn{6}{|l|}{$\begin{array}{l}\text { 4. Internet applications are best used in the classroom to promote students' } \\
\text { analytical, creative and other high order thinking skills. }\end{array}$} \\
\hline \multicolumn{6}{|l|}{$\begin{array}{l}\text { 5. Internet applications can be used in the classroom to provide alternative learning } \\
\text { approaches for students who are having difficulty in learning. }\end{array}$} \\
\hline \multicolumn{6}{|l|}{ 6. Using internet applications is an appropriate activity for some students. } \\
\hline \multicolumn{6}{|l|}{$\begin{array}{l}\text { 7. Using internet applications can be used in the classroom to make learning more } \\
\text { interesting for all students. }\end{array}$} \\
\hline \multicolumn{6}{|l|}{ 8. Information obtained from ESL/EFL websites is useful. } \\
\hline \multicolumn{6}{|l|}{ 9. Creating activities based on the Internet is useful. } \\
\hline \multicolumn{6}{|l|}{$\begin{array}{l}\text { 10. Through my learning experiences, I was motivated to learn English by the use of } \\
\text { the Internet. }\end{array}$} \\
\hline \multicolumn{6}{|l|}{$\begin{array}{l}\text { 11. Through my learning experiences, I improved English skills through the use of } \\
\text { the Internet. }\end{array}$} \\
\hline \multicolumn{6}{|l|}{$\begin{array}{l}\text { 12. Through my learning experiences, Internet resources provided me more } \\
\text { opportunities for autonomous learning. }\end{array}$} \\
\hline \multicolumn{6}{|l|}{$\begin{array}{l}\text { 13. Through my learning experiences, I improved my communication skills by } \\
\text { e-mailing or chatting with native speakers of English on-line. }\end{array}$} \\
\hline \multicolumn{6}{|l|}{$\begin{array}{l}\text { 14. Through my learning experiences, I was more attentive (careful) in } \\
\text { Internet-assisted English language teaching classes. }\end{array}$} \\
\hline \multicolumn{6}{|l|}{$\begin{array}{l}\text { 15. The Internet can provide non-native speakers of English with a rich learning } \\
\text { environment. }\end{array}$} \\
\hline \multicolumn{6}{|l|}{ 16. The Internet is a useful tool for helping me achieve my future learning purpose. } \\
\hline \multicolumn{6}{|l|}{ 17. In my belief, Internet resources can replace textbooks. } \\
\hline \multicolumn{6}{|l|}{ 18. In my belief, it is easy to find learning ESL/EFL materials on the Web. } \\
\hline \multicolumn{6}{|l|}{ 19. In my belief, ESL/ EFL Websites are useful for learning English. } \\
\hline \multicolumn{6}{|l|}{$\begin{array}{l}\text { 20. I think I would like to use Internet assisted language learning materials and } \\
\text { activities in my future EFL learning as much as possible. }\end{array}$} \\
\hline \multicolumn{6}{|l|}{ 21. I think I am competent to use Internet- based materials in my future learning. } \\
\hline \multicolumn{6}{|l|}{ 22. I think I need more technology training to improve my Internet literacy skills. } \\
\hline \multicolumn{6}{|l|}{$\begin{array}{l}\text { 23. I think I have to further learn how to integrate Internet resources into my future } \\
\text { learning. }\end{array}$} \\
\hline 24. I can get more current information from the Internet rather than from printed & & & & & \\
\hline
\end{tabular}


Kia Heirati, J., \& Ahmadi Alashti, L.

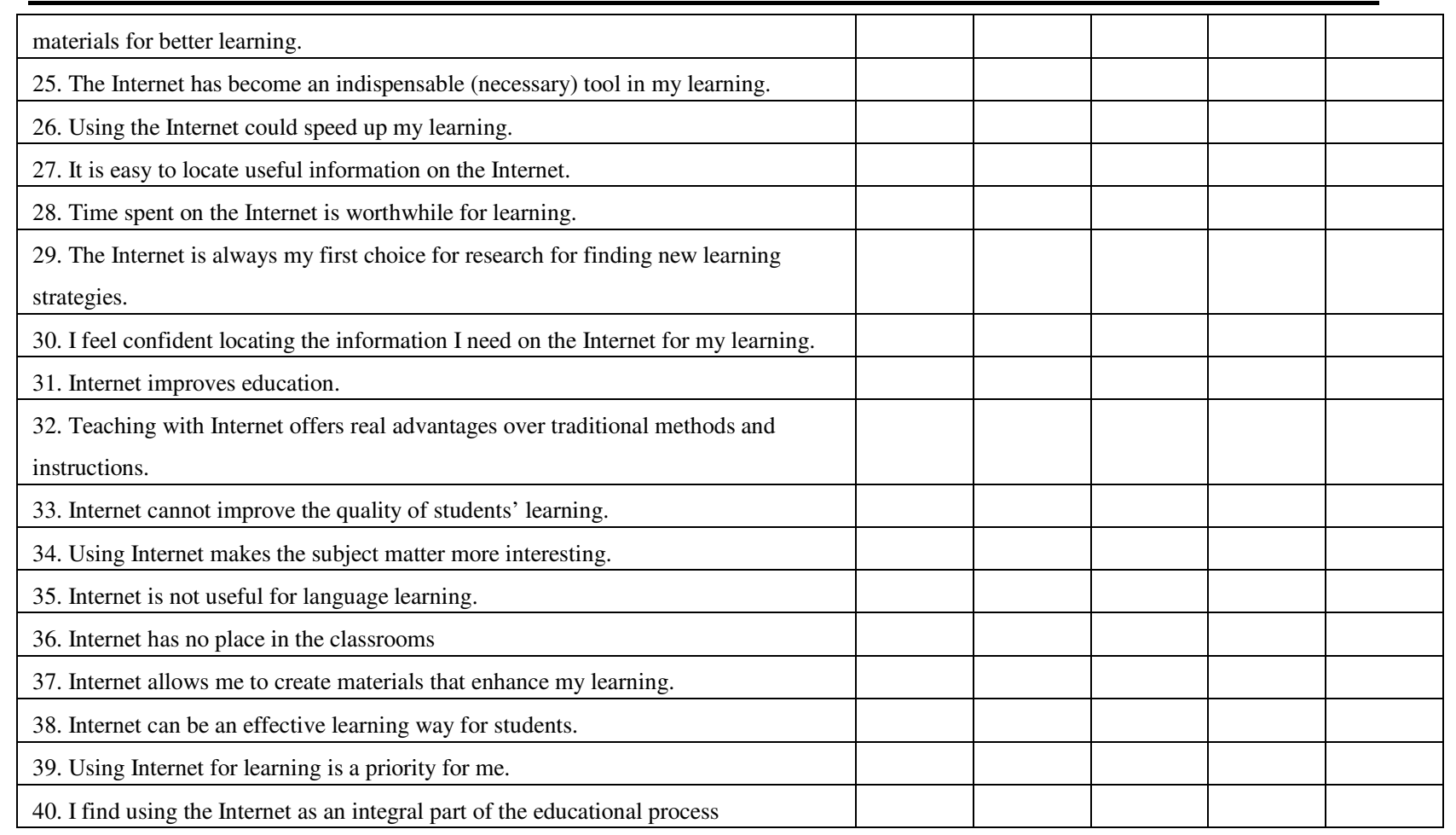

